Original Research Paper

\title{
Developing a Geographic Information System-Based Assessment Model for Sustainable Metropolitan Development: The Case of the Semarang Metropolitan Region, Indonesia
}

\author{
${ }^{1}$ Imam Buchori, ${ }^{2}$ Agung Sugiri, ${ }^{3}$ Sudharto P Hadi, ${ }^{4}$ David Wadley and ${ }^{5}$ Yan Liu \\ ${ }^{1,2,3}$ Diponegoro University, Semarang, Indonesia \\ ${ }^{4,5}$ University of Queensland, Australia
}

Article history

Revised: 24-03-2015

Accepted: 25-04-2015

Corresponding Author: Imam Buchori

Diponegoro University,

Semarang, Indonesia

Email: i.buchori@undip.ac.id
Received: 26-12-2014

\begin{abstract}
Spatial dynamics of metropolitan development are becoming important issues in sustainable development. In developing countries like Indonesia, the growth of metropolitan regions is often followed by problems of unsustainability. Therefore, a framework of assessment for metropolitan development can be useful as an early means of identifying any untoward aspects. This study aims to develop an assessment system that is easily applicable (user-friendly) in assessing metropolitan development in Indonesia. It is a Geographic Information System (GIS)based spatial model formulated as a simple Decision Support System (DSS), within which information can be queried down to district (kecamatan) level. As a test case, the model was applied in the Semarang Metropolitan Region of Central Java. The results show that it is capable of documenting and assessing the level of sustainability of the region. However, the lack of data at the kecamatan level is the main barrier to the application and development of the technique. Consequently, an in-depth study involving intensive dissemination of the concept, initiative and promulgation of initial results is subsequently proposed so that awareness of the local decision makers of the Indonesian government can be improved.
\end{abstract}

Keywords: Assessment Model, Sustainable Metropolitan Development, GIS, DSS

\section{Introduction}

Sustainable development aims to achieve intra-and inter-generational equity, by ensuring a balance of economic and environmental development (Pearce et al., 1989; Pearce and Warford, 1993; WCED, 1987). Viewed globally, regional and metropolitan development is uppermost among the important issues in the quest for sustainability. Regional development activities should be aligned with local stakeholders' efforts and can have economic, social as well as environmental impacts upon other regions within the country or even internationally. For example, a decision to develop a large industrial center, on the one hand could promote national economic growth. On the other, it could produce considerable pollution, which in turn could endanger the environment. These environmental issues could become regional, national or even global concerns.
The rapid growth of cities' development in Indonesia brings a variety of positive and negative effects. Development that can improve the quality of life can recursively cause environmental degradation, which threatens longer-term sustainability. Among the contraindications is the uncontrolled growth frequently appearing in major cities in Indonesia (Sugiri et al., 2011). Some regions appointed as national growth centers focus more on economic growth than equity and environmental issues. Serious environmental degradation in Java such as in Jakarta Bay and the Madura Strait, emanating from industrial and other economic activities in the metropolitan development of Jakarta and Surabaya can best portray this situation (Mukaryanti, 1997). Land use changes to more productive economic activities are usually available to minorities with access to the resources. Exploitation and industrialization in the rich natural resource regions like Aceh, Riau, East 
Kalimantan and Papua are apt to deliver fewer benefits to the local people (Mubyarto, 1998; Sugiri, 2009; Sugiri and Adiputra, 2011). Such situations could, therefore, worsen the overall national balance of equity.

The spatial dynamics of the Semarang Metropolitan Region (SMR) in Indonesia also present similar problems. Spatial interactions, especially journeys to work, use inefficient transportation energy (Soetomo, 2009). The continuing sprawl of urban areas proposes ineffective public infrastructure development. Residential areas come to occupy supposedly conserved lands (Soetomo, 2009; Khadiyanto, 2005). Rural-urban linkages fail to alleviate poverty, as indicated by trend lines since 2000 (Sugiri, 2008).

To address the problems of unsustainability in metropolitan development, Sugiri et al. (2011) developed a model of sustainable metropolitan development. This approach, the framework of which was developed around equity-based development (Sugiri, 2009), aims to manage metropolitan spatial dynamics to achieve greater sustainability. It has four drivers or purposes, formulated into eleven strategic policy aspects. The model was applied by Buchori and Sugiri (2013) to examine the development of Semarang City (the core part of the SMR). The findings show a trend of unsustainability in urban development. This is clearly not good; however, the more important issue is that these keynote studies need to be further enhanced so that the benefits can be gained by all stakeholders, including urban and regional development managers nationwide.

It is critical that previous studies converge toward an accepted model of sustainable metropolitan development (Sugiri et al., 2011). Meanwhile, the assessment framework (Buchori and Sugiri, 2013) needs to be further developed as a system that is easily applicable (userfriendly) so that benefits available from metropolitan development in Indonesia can be readily achieved.

This project proposes a GIS-based assessment model for the whole SMR, within which information can be queried down to district (kecamatan) level. The study area covers four Kabupaten (Kendal, Demak, Semarang and Purwodadi) and two Cities (Semarang and Salatiga) locally known as Kedungsepur, an acronym of the names of members of the metropolitan ensemble, with Semarang City as the core of the region. The model was formulated as a simple Decision Support System (DSS), in the form of a GIS-based spatial model.

\section{DSS-Spatial Model Based on GIS}

By definition, a spatial model represents spatial information relating to kindred aspects, such as socioeconomic and cultural information. Wegener (1999) states that such a model investigates bi-space (map and attribute). Despotakis et al. (1993) regard a spatial model as an accurate and intuitive description of reality in map form. The completeness of the initiative is accomplished through logical deduction, in that attention is directed from the whole to its specific parts, seeking to find simplified relationships, interdependencies and influences.

Presently, spatial modeling is mostly associated with the use of Geographic Information Systems. In more advanced usage, a spatial model can be integrated into a Decision Support System (DSS) (Buchori, 2005), as seen in Fig. 1. A dynamic model can be defined as one capable of describing phenomena, which change over time. During the last few decades, researchers have increased their interest in GIS for modeling spatiotemporal processes due to its capability to integrate spatial and temporal information and to represent data changing in time and space (Marceau et al., 2001). Both the dynamic model and the GIS contain features necessary for solving complex problems. Integrating the two will allow more adequate solutions to spatial problems in the future (Barredo et al., 2003; Han et al., 2009; Chang et al., 2008; Xiaodan et al., 2010).

An example of this integration is Dispotakis' model (1990), which uses a dynamic system in a GIS environment to identify and evaluate various strategies and development scenarios within an encompassing evaluation of the Greek islands. Another example is Marceau et al. (2001) model, which integrates a temporal topology in a GIS database to study the land use changes in a rural-urban environment. Of related interest is a simulation model of the Cooum River developed by Bunch and Dudycha (2004), involving a conceptual model of participatory development combining GIS-based DSS and an environmental model. More recently appearing is a contribution (Yeo et al., 2013), which uses a Geographical Information System Database (E-GIS DB) to create an urban planning support model relating to energy usage. In all these application, DSS has been employed to support planning processes involving several parameters.

The processed based dynamic GIS models occur not only in their maps' topologies (polygon, line, or point) but also in their thematic attributes (tabular data). The integration of socioeconomic models, such as population growth, the input-output model, the dynamic general equilibrium model, etc. and GIS can help regional managers understand dynamic aspects of the spatial changes.

GISs naturally become more powerful when linked with DSSs (Schotten et al., 2001). By definition, a DSS is a computer system helping one or more actors in their work of making decisions (Laurini, 2001). It provides a framework for integrating database management systems, analytical models and graphics to assist in improving decision-making process (Yeh, 
1999). Nyerges (1999) argues that a GIS-model cannot be distinguished from a DSS-model. He defines GIS as a DSS that involves geo-referenced data for the area of problem-solving environment. Likewise, Yeh (1999) argues that the distinction between GIS and DSS models becomes blurred because of the high speed of GIS software improvements in the future.

On the other hand, there is also widespread skepticism of how to integrate GIS with DSS. Nyerges (1999) maintain that the research literature still lacks theoretical and empirical contributions to GIS application for specific topics of DSS because many studies seem to focus more on software development. Laurini (2001), considering expert systems for urban planning as comprehensive, asserts that previous experiments have remained at the prototypical or academic levels of implementation instead of being used operationally. The integration of spatial topology and geometry into an expert system has been the main difficulty. He explains that colleagues who have attempted to establish DSSs for master plan designs have been thwarted due to difficulties relating both to how to describe rules verbally and also to the question of how to formalize them as an expert system rule.

Conversely, Laurini (2001) offers some success stories of DSS applications for selected issues in planning, such as in site selection, traffic control and the resolution of environmental disputes. Researchers have also successfully developed spatial information models of DSS, including McClean and Fuller (1995) with a DSS-model for land use planning, Czeranka (1997) with a DSS-model for natural conservation and spatial planning, Nyerges (1999) in spatial decision making, De Kok et al. (2001) in proposing a land use change-DSS-model for coastal zone management, Kyariga (2001) for a DSS-model for urban planning and management, Chowdary et al. (2003) for a DSSmodel for groundwater assessment, Arampatzis et al. (2004) for a DSS-model for urban transportation planning and policies, Zeng et al. (2007) for their DSS-model for risk assessment of wind damage in forest management, Chang et al. (2008) for a DSSmodel for sustainable coral reef management in coastal zone, Countinho-Rodrigues et al. (2011) for their multi-criteria e-DSS for urban infrastructure planning and De Meyer et al. (2013) for the DSSmodel for land use planning. According to this optimistic view, a combination of GIS and DSS modeling is viable now and in the future.

The current model, the assessment framework developed in this study, is a combination of GIS and a simple DSS-based application. It seeks to help decision makers at metropolitan region to assess the sustainability of urban and regional development in their territory. It might not be "a real DSS-model", by which users can overcome their problems, but it should equate to a powerful tool that can provide adequate information required by urban or regional managers to make strategic decisions.

\section{The Concept of an Assessment Framework Model for Metropolitan Development}

The scope of the assessment framework developed in this study is as follows:

- Developing the concept of an assessment framework. The framework is formulated as an ArcView project file, consisting of four modules, each of which contains several district-based indicators of sustainability. The modules represent four capabilities to undergird the model of sustainable metropolitan development proposed by Sugiri et al. (2011). Evaluative indicators are extracted from the strategies proposed within the model. As for the software, ArcView is used because of its facilitative user interface. ArcView is equipped with a simple language program embedded in the software, named Avenue. Meanwhile, to develop a user interface in the newer version of ESRI's GIS-software, i.e., Arc GIS, one should use a general language program beyond GIS-software, such as $\mathrm{C}++$ or, Visual Basic, etc. However, since Arc GIS has more capability to generate and analyze maps, it has been used in this study for such purposes

- The development of the assessment concept for each module. The idea is that the assessment should be quantitative wherever possible. A simple weighted method is developed for each module in respect of sustainable outcomes

- The application of the concept to the Semarang Metropolitan Region. The application has been used to test the suitability of the framework. It needs spatial data, such as: The base map (administrative map of Kedungsepur by districts), namely, the BIG's (BadanInformasiGeospasial/National Agency for Geospatial Information) map at the scale of $1: 25,000$ and a land use map at the same scale. In some cases, the land use map has also been generated from satellite imagery

- Evaluation of the developed framework. Evaluation is necessary to assess whether the purpose of the study is achieved. The outputs of the evaluation should be some suggestions to improve the framework and ideas for further studies

Figure 2 outlines the concept of the assessment framework for metropolitan development. It contains 
four modules, each of which has several sustainability indicators. Explanations of the selected indicators are offered in due course. Each module represents a facet of sustainability, as follows:

- The Module of Minimizing Energy represents an ability of the spatial structure and function to minimize the use of energy and natural resources for a certain level of development

- The Module of Optimizing the Social Situation represents an ability to ensure, among the activities within the region and in relation to other regions, a socially optimal situation regarding negative externalities between socioeconomic activities and the environment

- The Module of Comparative Advantage reflects the ability to strengthen the comparative advantages of the region

- The Module of Involving People enquires into the proportion of people involved in productive activities

\section{Application of the Concept in the Semarang Metropolitan Region}

The file of the SMR framework is an ArcView project file. When opened, the first main feature to appear is a choice-diagram explaining the four modules, as represented in Fig. 3 and 4. The file has password protection to avoid any usage by inappropriate persons.

The development of each module consists of several stages as explained in Fig. 5.

The first stage is to re-assess the indicators. Since the information unit is district (kecamatan), not all of the defined indicators can be used because of nonavailability of data and suitability of the information. The second stage is to define the design of the information system, proposing how data are organized and displayed. The design is drawn via the boxes of a flowchart, each of which represents the name of a View, an explanation of the View, the type of information, the shp-files presented in the View and the table presented together with the View (Fig. 6).

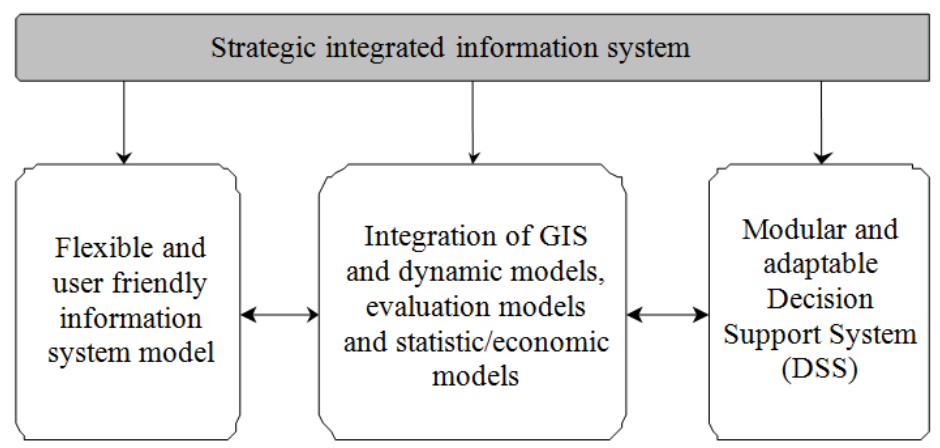

Fig. 1. Strategic integrated information system (Source: Modified form Fischer and Nijkamp, 1993)

\begin{tabular}{|l|l|l|}
\hline $\begin{array}{l}\text { Spatial } \\
\text { Information: } \\
\text {-Attribute data } \\
\text {-Graphical data } \\
\text { (maps) }\end{array}$ \\
\hline $\begin{array}{l}\text { Concept of } \\
\text { sustainability } \\
\text { assessment } \\
\text { framework: } \\
\text {-Visualizing } \\
\text {-Querying } \\
\text {-Analyzing } \\
\text {-Up dating } \\
\text {-Printing } \\
\text { •Etc. }\end{array}$
\end{tabular}

Fig. 2. Concept of assessment framework (Source: Developed from Sugiri et al., 2011) 


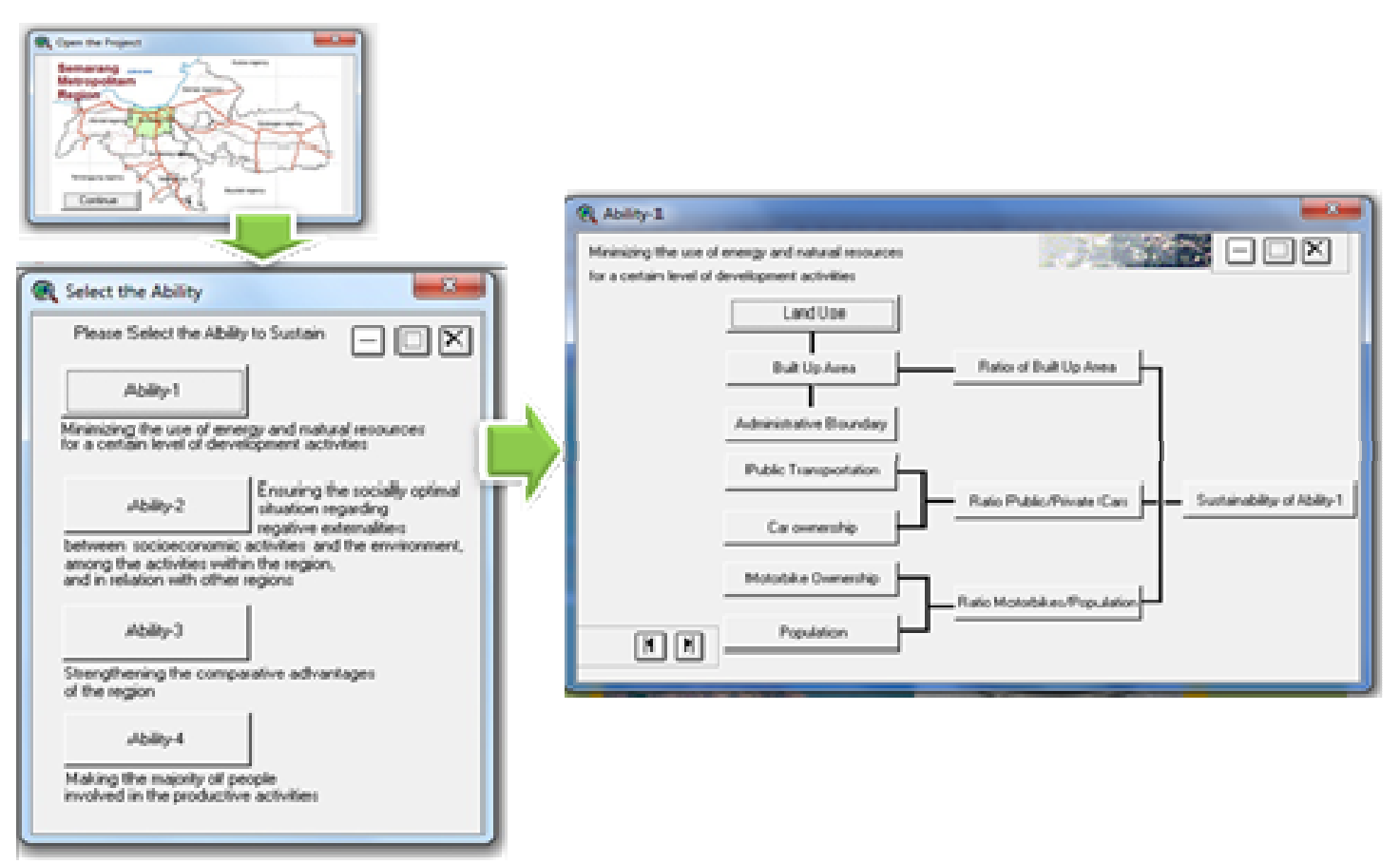

Fig. 3. Preview of opening the file (Source: Own compilation)

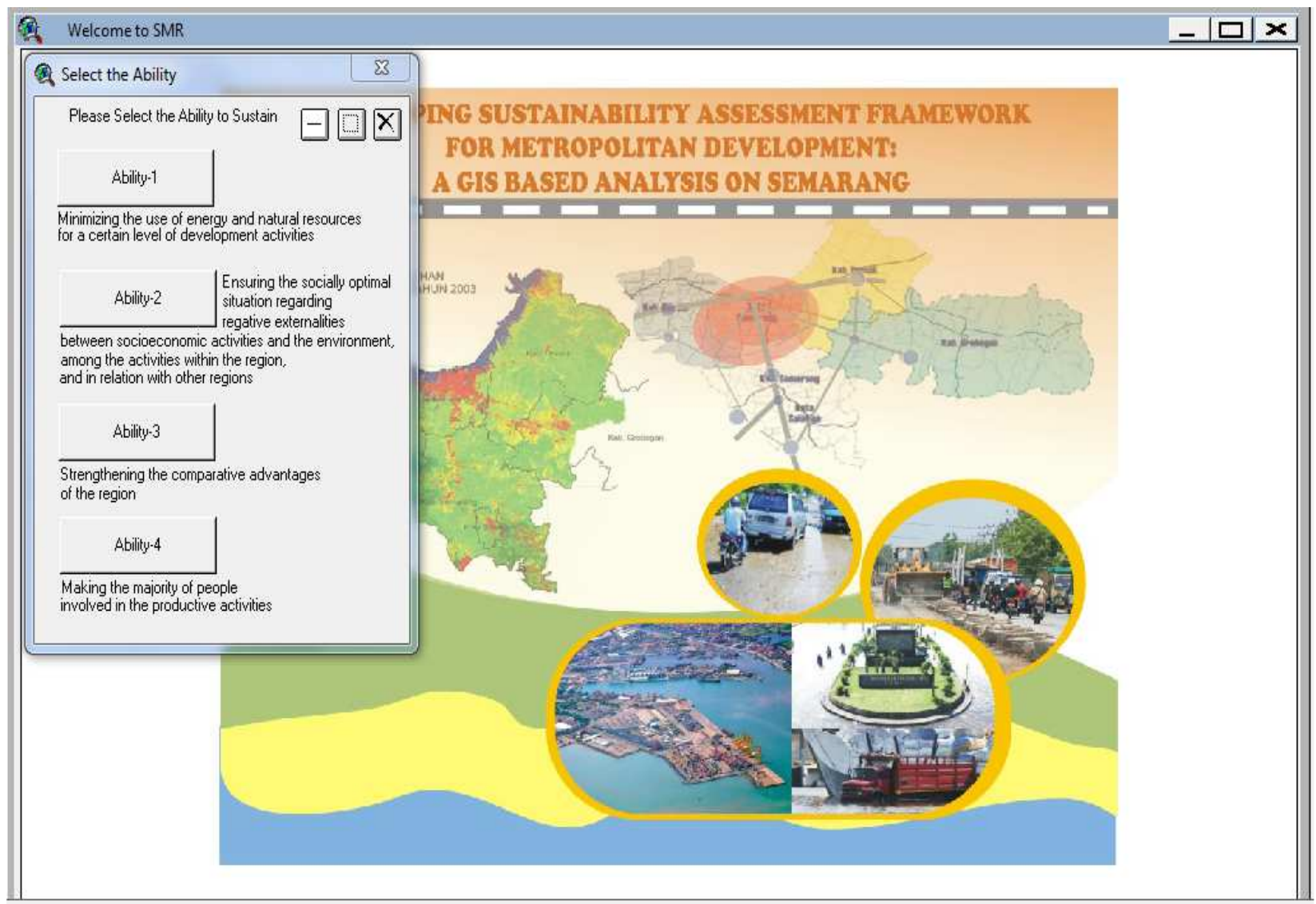

Fig. 4. Preview of the information system (Source: Authors) 


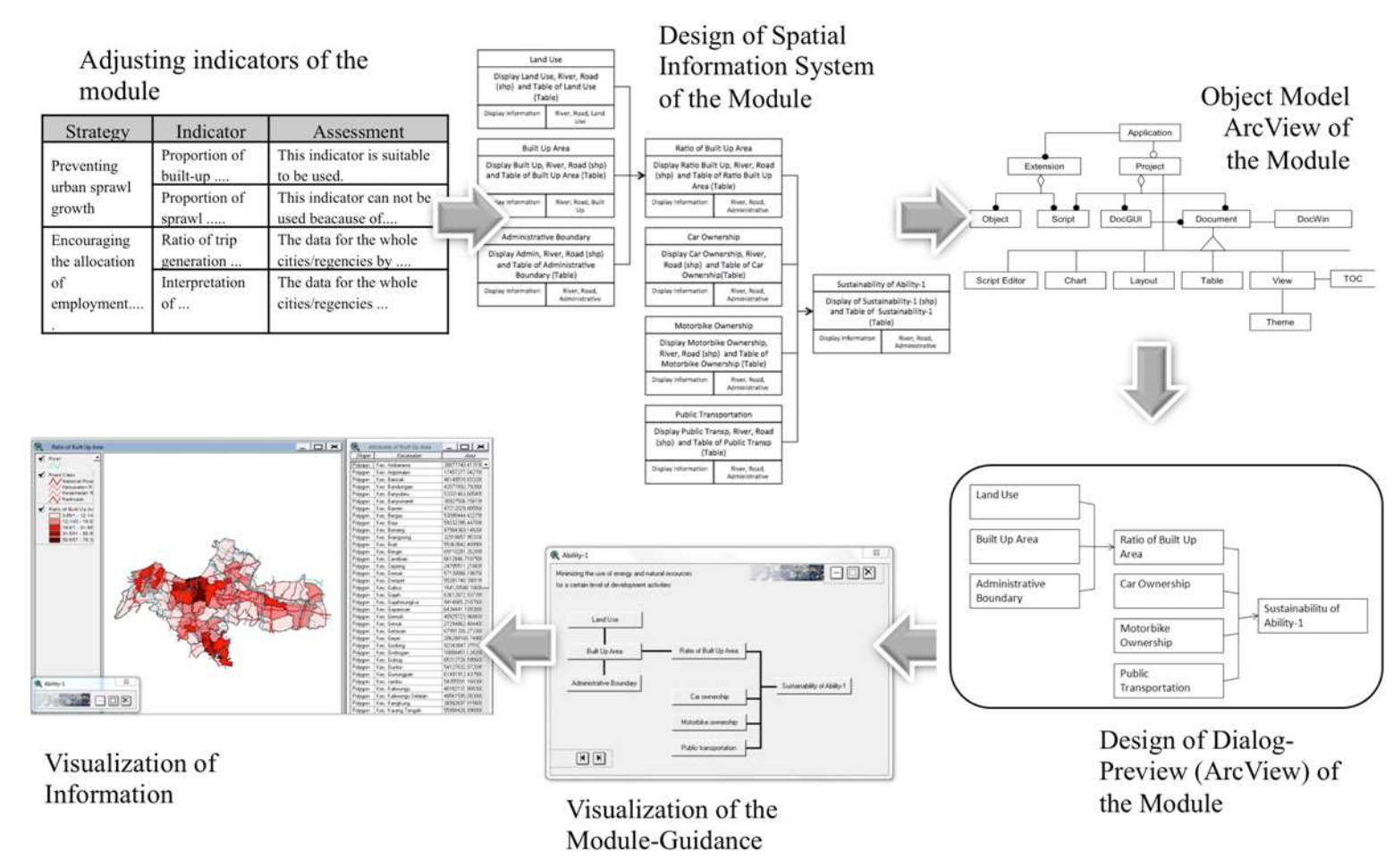

Fig. 5. Stages of spatial information system of each module (Source: Authors)

\begin{tabular}{|c|c|}
\hline \multicolumn{2}{|c|}{ Name of View } \\
\hline \multicolumn{2}{|c|}{ Explanation about the View } \\
\hline $\begin{array}{c}\text { Spatial } \\
\text { Information }\end{array}$ & $\begin{array}{c}\text { List of SHP-File } \\
\text { presented }\end{array}$ \\
\hline
\end{tabular}

Fig. 6. Legend of boxes in design of information system (Source: Own compilation)

The third stage is to design the concept of the object model, which is a diagram containing several boxes, representing classes and lines, representing the relationship between those boxes. Then, the fourth stage is to develop the user interface's dialog panel. It is one of ArcView's tools which can be used to manage the visualization of information and to represent the guidelines of each module of assessment. Users are allowed to select the information they want to display using this dialog panel. The menu of choice is represented by some label buttons, one of the dialog tools in ArcView. The final stage is to actualize this concept into a GIS-model as an ArcView project file. This file is not an independent application file (exe-file), which can be directly installed on such operation systems like Windows, Linux, etc., but can only be run with ArcView software.

We turn now to an explanation of the contents of each module.

\section{Minimizing Energy}

Based on the Sugiri et al. (2011), the ability to minimize the use of energy and natural resources for a certain level of development activities ("Ability-1") can be accomplished through four strategies (Table 1). For each strategy, several indicators have been developed. Unfortunately, not all can be represented in a kecamatan-based unit. Besides, not all of the data needed could be gathered from the city/regency agencies in the SMR. It was often found that certain data were available in some cities/regencies but not in the others. Therefore, the indicators developed in the model have been re-assessed according to two criteria: (1) Their suitability to be represented as a districtbased unit and (2) data availability in the entire set of cities/regencies involved in the SMR.

Based on this assessment, the indicators used in the module of Ability-1 $\left(\mathrm{A}_{1}\right)$ are: (1) the proportion of the built-up area $\left(\mathrm{X}_{11}\right) ;(2)$ the ratio of private to public cars $\left(\mathrm{X}_{12}\right)$; and (3) ratio of motorbikes to population $\left(\mathrm{X}_{13}\right)$. The logic relating to the level of sustainability is that the higher the number of the first, second and third indicators, the lower the level of districts' sustainability.

The level of sustainability of each indicator is then adjusted, as shown in Table 2. It comprises "unsustainable", "less sustainable" and "sustainable". The final assessment is the sustainability of the Ability-1 $\left(\mathrm{X}_{1^{-}}\right)$, which is also distinguished by three levels, i.e., "unsustainable", "less sustainable" and "sustainable". 
Table 1. Assessment for Indicators of the Module of Ability-1

\begin{tabular}{|c|c|c|}
\hline Strategy & Indicator & Assessment \\
\hline $\begin{array}{l}\text { 1. Preventing urban } \\
\text { sprawl growth. }\end{array}$ & $\begin{array}{l}\text { Proportion of built-up area to } \\
\text { administrative area }\left(\mathrm{X}_{11}\right) .\end{array}$ & This indicator is available to be used. \\
\hline & $\begin{array}{l}\text { Proportion of sprawl growth } \\
\text { area to built-up area. }\end{array}$ & $\begin{array}{l}\text { This indicator cannot be used because of difficulties } \\
\text { in defining built up areas in each district unit. }\end{array}$ \\
\hline $\begin{array}{l}\text { 2. Encouraging the allocation } \\
\text { of employment and activities to } \\
\text { their appropriate locations based }\end{array}$ & $\begin{array}{l}\text { Ratio of trip generation rates between } \\
\text { suburbs and the CBD. } \\
\text { Interpretation of Origin-Destination }\end{array}$ & $\begin{array}{l}\text { The data for the entire cities/regencies by district } \\
\text { are not available (only for Semarang City). } \\
\text { Same as above. }\end{array}$ \\
\hline
\end{tabular}

system of central pla

3. Allocating agricultural and

other primary-sector activities

in the most physically-suitable

land.

4. Encouraging the development

of the best possible regional

transport system.

\section{Percentage of existing land use that is most suitable.}

Growth rate of private cars.

Growth rate of public transport buses and minibuses.

Growth rate of motor bikes.
This indicator is not used because it is suitable for just rural areas. Besides, the land suitability analysis by district cannot be accomplished because the data are not available.

The data for the whole district are available but only for 2010. The indicator is therefore changed to "ratio between private and public cars" $\left(\mathrm{X}_{12}\right)$.

The data for the whole district are available but only for 2010. The indicator is changed to "ratio of motorbikes to population" $\left(\mathrm{X}_{13}\right)$.

\section{(Source: Own analysis)}

Table 2. Level of sustainability of indicators of the module of Ability-1

\begin{tabular}{lll}
\hline Indicator & Level of sustainability & Score \\
\hline 1. The proportion of built up area $\left(\mathrm{X}_{11}\right)$; the & $\bullet 30 \%=$ unsustainable & 1 \\
ratio between built up area and total area of & $\bullet 15-30 \%=$ less sustainable & 2 \\
each kecamatan & $\bullet<15 \%=$ sustainable & 3 \\
2. The ratio of private to public cars $\left(\mathrm{X}_{12}\right)$ & $\bullet>150=$ unsustainable & 2 \\
& $\bullet 50-150=$ less sustainable & 3 \\
3. The ratio of motorbikes to population $\left(\mathrm{X}_{13}\right)$ & $\bullet<50=$ sustainable & 1 \\
& $\bullet>0.20=$ unsustainable & 2 \\
Sustainability of Ability-1 $\left(\mathrm{X}_{1-}\right)$ & $\bullet 0.12-0.20=$ less sustainable & 3 \\
Score $=\mathrm{X}_{11}+\mathrm{X}_{12}+\mathrm{X}_{13}$ & $\bullet<0.12=$ sustainable & $3-5$ \\
& $\bullet$ Unsustainable & $6-7$ \\
\hline
\end{tabular}

(Source: Own analysis)

\section{Ensuring Socially Optimal Situation}

The ability to ensure a socially optimal situation in relation to negative externalities between socioeconomic activities and the environment, among the activities within the region and in consort with other regions (hereafter known as “Ability-2") has two strategies. They have been encapsulated into two and three indicators. Thus, there are in total five indicators. Among them, three were selected to be used in the module of Ability-2. As shown in Table 3, they are: (1) Availability of a Regional/City Master Plan $\left(\mathrm{X}_{21}\right)$; (2) Availability of an Environmental Impact Assessment $\left(\mathrm{X}_{22}\right)$; and (3) Availability of a Detail Plan (Spatial Master Plan) for Industry $\left(\mathrm{X}_{23}\right)$.

The level of sustainability of each indicator is then adjusted, as "available" and "unavailable". The final assessment is the sustainability of the Ability-2 $\left(\mathrm{X}_{2^{-}}\right)$, i.e., the sum of those three indicators distinguished by "unsustainable", "less sustainable" and "sustainable" (Table 4).

\section{Strengthening Comparative Advantages}

The ability to strengthen the comparative advantages of the region has three strategies, i.e., encouraging conversion of uses that can strengthen or create comparative advantages as long as socioeconomic efficiency is maintained; advocating efforts to increase land use productivity under conditions of socioeconomic efficiency; and encouraging traditional or indigenous utilization of land, especially in primary sector activities, if this leads to a socially optimal situation. These three strategies are then molded into eight sub-strategies. Unfortunately, the second and the third strategies that relate more to agricultural activities are applicable only to rural areas whereas the framework in question is designed for metropolitan areas containing urban and rural areas. 
Besides, to represent such information at district level is difficult. Therefore, only the indicators derived from the first strategy are used in the module of Ability-3, i.e., (1)
Availability of incentives or-disincentives for land use $\left(\mathrm{X}_{31}\right)$; and (2) Deviation of the existing land use from the Land Use Plan $\left(\mathrm{X}_{32}\right)$, are shown in Table 5.

Table 3. Assessment for the indicators of the module of Ability-2

\begin{tabular}{ll}
\hline Strategy & Indicator \\
\hline 1. Facilitating segregation of all & The extent of successful implementation \\
polluting activities, from large scale & of the City Master Plan in this regard
\end{tabular}

to small scale ones

of the City Master Plan in this regard

Assessment

To be linked with data availability and

information unit at district level, this indicator is changed to "Availability of City/Regional Master Plan" $\left(\mathrm{X}_{21}\right)$

Availability of an incentive-disincentive This indicator cannot be applied at a district mechanism for polluting industries level because the data are not available.

2. Applying a Command and Control (CAC) approach, complemented with Market Based Instruments (MBIs) in dealing with pollution and other forms of externality to all land uses

Interpretation of local regulation for This indicator cannot be applied at a district industrial development level because the data are not available. Availability of Environmental Impact This indicator can be applied.

Analysis (EIA) $\left(\mathrm{X}_{22}\right)$

Availability of detailed spatial plans This indicator can be applied.

(Source: Authors) for industrial development $\left(\mathrm{X}_{23}\right)$

Table 4. Level of sustainability of indicators of the module of Ability-2 Indicator

1. Availability of a Regional/City Master Plan

2. Availability of an Environmental Impact Assessment;

3. Availability of a Detail Plan (Spatial Master Plan) for Industry

Sustainability of Ability-2 $\left(\mathrm{X}_{2}-\right)$

Score $=\mathrm{X}_{21}+\mathrm{X}_{22}+\mathrm{X}_{23}$

$\begin{array}{ll}\text { Level of sustainability } & \text { Score } \\ \text { - Un-available } & 0 \\ \text { - Available } & 1 \\ \text { - Un-available } & 0 \\ \text { - Available } & 1 \\ \text { - Un-available } & 0 \\ \text { - Available } & 1 \\ \text { - Unsustainable } & 0-1 \\ \text { - Less sustainable } & 2 \\ \text { - Sustainable } & 3\end{array}$

(Source: Authors)

Table 5. Assessment for the indicators of the module of Ability-3

\begin{tabular}{|c|c|c|}
\hline Strategy & Indicator & Assessment \\
\hline $\begin{array}{l}\text { 1. Encouraging conversion of uses that } \\
\text { can strengthen or create comparative } \\
\text { advantages, as long as the socioeconomic }\end{array}$ & $\begin{array}{l}\text { Availability of incentive-disincentive } \\
\text { mechanism for land use, e.g., in zoning } \\
\text { regulation }\left(\mathrm{X}_{31}\right)\end{array}$ & $\begin{array}{l}\text { This indicator is suitable to be applied, } \\
\text { but is changed into "availability of } \\
\text { incentive-disincentive for land use". }\end{array}$ \\
\hline
\end{tabular}

advantages, as long as the socioeconomic efficiency is maintained

2. Advocating efforts to increas land use productivity under the condition of socioeconomic efficiency

3. Encouraging traditional or indigenous utilization of land, especially in primary sector activities, if this leads to socially optimal situation.

(Source: Authors)
Percentage of land use deviation from the Plan $\left(\mathrm{X}_{32}\right)$

Availability of local regulations

Production scale of agriculture related industries

Investment for modern technologies in agriculture

Number of elucidation personnel per area unit of agriculture land

Availability of local wisdom applied in agriculture

Availability of regulations on the use of Same as above. chemicals for agriculture
This indicator is suitable to be applied. The deviations measured are not for all kinds of land use but are limited to residential areas in order to reduce the volume of work.

This indicator is not used because the strategy is for rural areas, while this framework is for metropolitan, containing urban and rural characteristics detailed at district level.

Same as above.

Same as above.

Same as above.

Same as above. 
The level of sustainability of the first indicator $\left(\mathrm{X}_{31}\right)$ is then defined as "available" and "unavailable". The second indicator $\left(\mathrm{X}_{32}\right)$ is adjusted into "unsustainable", "less sustainable" and "sustainable". The final assessment is the sustainability of the Ability-3 ( $\left.\mathrm{X}_{3-}\right)$ distinguished by "unsustainable", "less sustainable" and "sustainable" (Table 6).

\section{Involving the Majority of People in Highly Productive Activities}

The ability to have the majority of people involved in the productive activities contains two strategies, i.e., facilitating the development of rural non-farm activities regardless of their formal or informal characteristics and advocating the best ratio of capital-intensive and laborintensive activities, especially when the expansion of capital-intensive activities is considered socially inefficient. The first strategy has three indicators and the second strategy just one. Based on the reassessment seen in Table 4, three indicators can be used in the module of Ability-4, i.e., (1) Numbers of establishments representing small scale industry $\left(\mathrm{X}_{41}\right)$; (2) Rate of jobs in small-scale activities $\left(\mathrm{X}_{42}\right)$; and (3) A comparison of labor-based and GRDP-based LQs for industry $\left(\mathrm{X}_{43}\right)$ Table 7.

Table 6. Level of sustainability of indicators of the module of Ability-3

\begin{tabular}{lll}
\hline Indicator & Level of sustainability & Score \\
\hline 1. Availability of incentives or-disincentives to regulate land use & $\bullet$ Un-available & 0 \\
& $\bullet$ Available & 1 \\
2. Deviation of existing land use from the Land Use Plan & $\bullet>10 \%=$ Unsustainable & 1 \\
& $\bullet 3-10 \%=$ Less sustainable & 2 \\
Sustainability of Ability-3 $\left(\mathrm{X}_{3-}\right)$ & $\bullet<3 \%=$ Sustainable & 3 \\
Score $=\mathrm{X}_{31}+\mathrm{X}_{32}$ & $\bullet$ Unsustainable & $1-2$ \\
& $\bullet$ Less sustainable & 3 \\
\hline
\end{tabular}

(Source: Authors)

Table 7. Assessment for the indicators of the module of Ability-4

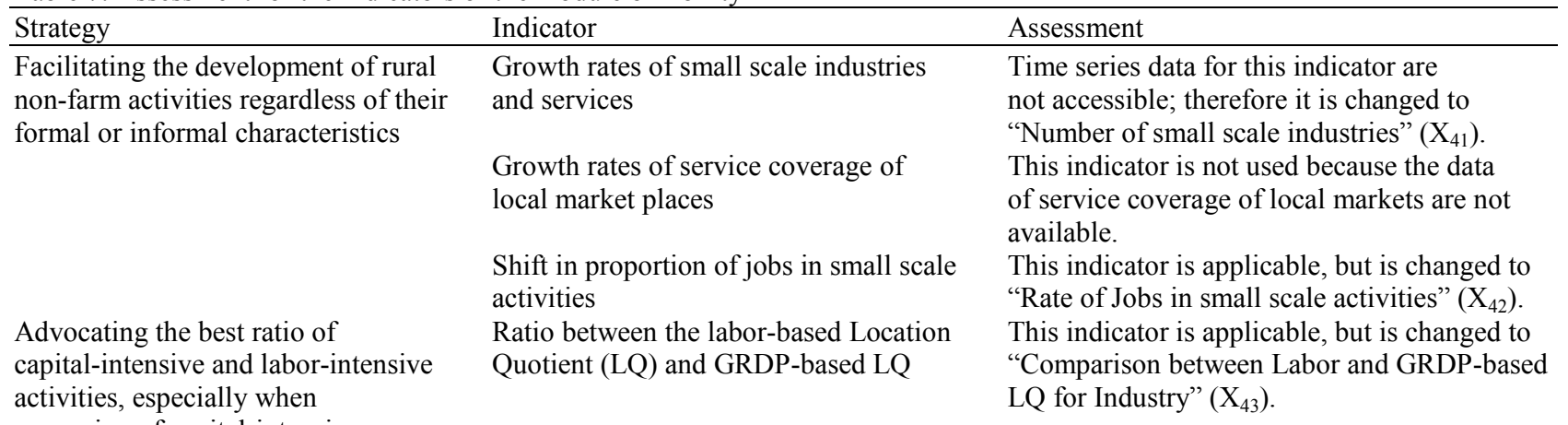

activities,

expansion of capital-intensive

activities is considered socially

inefficient

(Source: Authors)

Table 8 . Level of sustainability of indicators of the module of Ability-4

\begin{tabular}{lll}
\hline Indicator & Level of sustainability & Score \\
\hline 1. Numbers of establishments representing small scale industry $\left(\mathrm{X}_{41}\right)$ & $\bullet<75=$ unsustainable & 1 \\
& $\bullet 75-150=$ less sustainable & 2 \\
2. Ratio of jobs in small scale activities $\left(\mathrm{X}_{42}\right)$ & $\bullet>150=$ sustainable & 3 \\
& $\bullet<0.04=$ unsustainable & 1 \\
3. Comparison between Labor and GRDP-based LQ for Industry $\left(\mathrm{X}_{43}\right)$ & $\bullet 0.04-0.10=$ less sustainable & 2 \\
& $\bullet>0.10=$ sustainable & 3 \\
Sustainability of Ability-4 $\left(\mathrm{X}_{4-}\right)$ & $\bullet<0.80=$ unsustainable & 2 \\
Score $=\mathrm{X}_{41}+\mathrm{X}_{42}+\mathrm{X}_{43}$ & $\bullet 0.80-1.00=$ less sustainable & 3 \\
& $\bullet>1.00=$ sustainable & $3-4$ \\
\hline
\end{tabular}

(Source: Authors) 
The level of sustainability of each indicator is adjusted as "unsustainable", "less sustainable" and "sustainable". The final assessment is the sustainability of the Ability-4 $\left(\mathrm{X}_{4}\right)$, which is also distinguished by "unsustainable", "less sustainable" and "sustainable" (Table 8).

\section{Results and Discussion}

This discussion concentrates on the applicability of the model to the Semarang Metropolitan Region. Aspects at issue include: The results of the sustainability assessment of the SMR; to what extent the model can assess the sustainability of the SMR; whether the public authorities of the SMR can use the model easily; what would be needed to improve the applicability of the model; and what would be the next steps in continuing the study and refining the model.

The results of sustainability assessment using the model of the SMR can be seen in Fig. 7 to 10. Various results pertaining to the four abilities are shown. Overall, the less sustainable and unsustainable kecamatans outnumber the sustainable ones. Thus, the onset of unsustainability in the spatial development of the SMR is confirmed.

In Ability-1 (minimizing the use of energy and natural resources), the pattern of "the more an area is urbanized, the less the sustainability level" is apparent. A similar pattern is also there for Ability-3 (strengthening the comparative advantages) although to a lesser extent because some rural kecamatans are also marked as unsustainable, especially in Kabupatens Demak and Purwodadi.

This 'more urbanized less sustainable' pattern for Ability-1 of the spatial structure and function of the SMR is not surprising as cost effectiveness can hardly be ensured in urban spatial dynamics, especially in the use of transport energy (Black, 2009; Dassen et al., 2013; Firman, 2009). However, a similar pattern for Ability-3 can be seen as positive in rural areas, except those in Kabupatens Demak and Purwodadi, but negative for urban areas of the SMR. In general, the comparative advantages of the rural areas appear well placed; such, however, is not the case for the urban areas. The lack of data has made it possible to measure only the strategy of land use conversion and it is worth noting that land use conversion in urban areas tends not to encourage comparativeness, perhaps because urban economic actors are more concerned with the competitiveness.

Meanwhile, different patterns are found for Ability-2 (ensuring a socially optimal situation) and Ability-4 (involving the majority of people in productive activities). Both facets seem to be random. Ability-2 is probably the most promising among the four abilities of the spatial structure and function of the SMR. There is no district marked as unsustainable here, although only some kecamatans are categorized as sustainable (Fig. 9). So, a condition of "less sustainable" is dominant, which means that problems with negative externalities are still significant and to be resolved.

For ability-4, although the spatial patterning also seems random, it should be noted that significant numbers of rural districts, especially those in Kabupatens Kendal, Semarang, Demak and Purwodadi, are marked as "unsustainable" while many others are "less sustainable". There is a serious threat of unsustainability because the ability to involve the majority people in highly productive activities should first and foremost occur in rural areas. Not only will this development encourage poverty alleviation, but will lessen rural-urban inequality (Sugiri et al., 2014). So, it can be said that the pattern for Ability-4 tends to be "the more rural an area is, the less the sustainability would be".

In general, data availability is the most important limitation of this study. Lack of data has forced many changes in indicators and even cancelation of some of them. So, it is worth questioning to what extent the model application can assess the sustainability of the SMR.

As described previously, the model is meant to assess the sustainability through the performance of four abilities comprising 11 strategies of sustainable metropolitan development. For Ability-1, only two out of four strategies were measured, but with significant changes in some indicators. For Ability-2, although all two strategies were assessed, significant modifications of indicators were also made. For Ability-3, only one, out of three, strategy was measured and slight changes in indicators were also made. Finally for Ability-4, all two strategies were measured, but with significant changes in indicators. Therefore, it can be said that the model application on the SMR can assess about $70 \%$-at maximum-of the situation.

Meanwhile, although there is an essential need to improve the applicability of the model, the prospect of the local government officers of the SMR to use the model is quite good. The GIS-based model has been made easy to use while the software needed is available in the local governments of the SMR. However, the application should be coordinated by Central Java Provincial Government since it is an inter-local governmental issue. For nationwide, the prospect is also good, especially for the western part of Indonesia. However, capacity building may be needed and equipment help should most probably be given to local governments in eastern Indonesia.

As for to improve the applicability of the model, data completion is a must so that the original design of indicators can be fully applied. Additional work should be done by local governments, which would like to apply the model. Statistical Bureau and Bappeda (Regional Development Planning Board) will have the most important role for this purpose. 


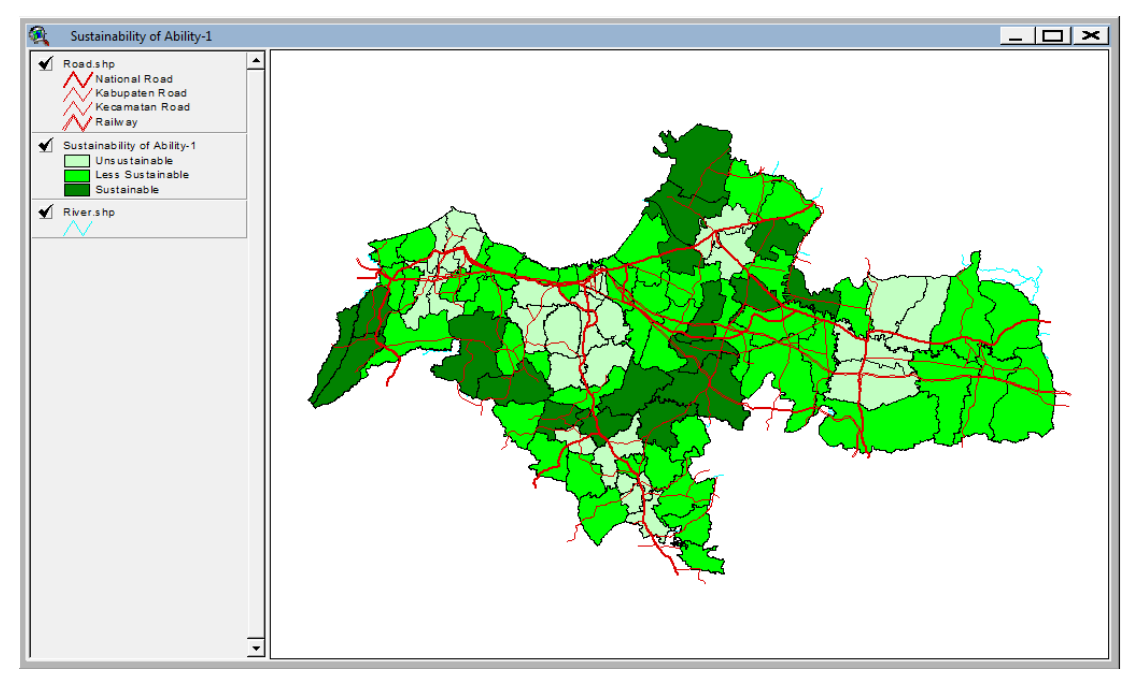

Fig. 7. Sustainability of Ability-1 of the SMR (Source: Authors)

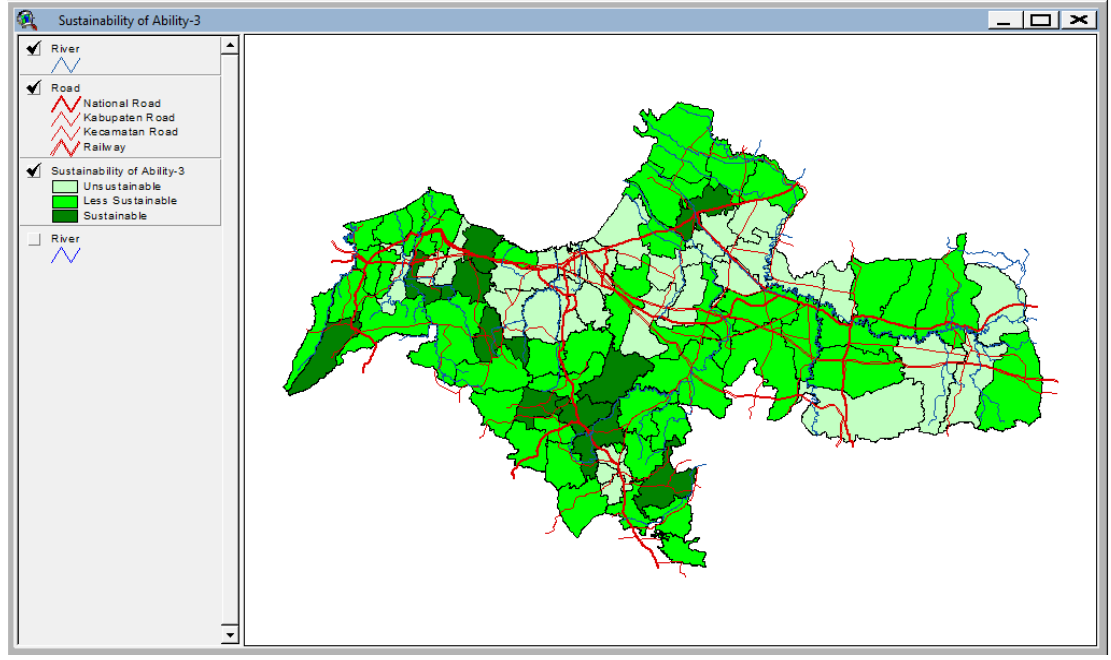

Fig. 8. Sustainability of Ability-3 of the SMR (Source: Authors)

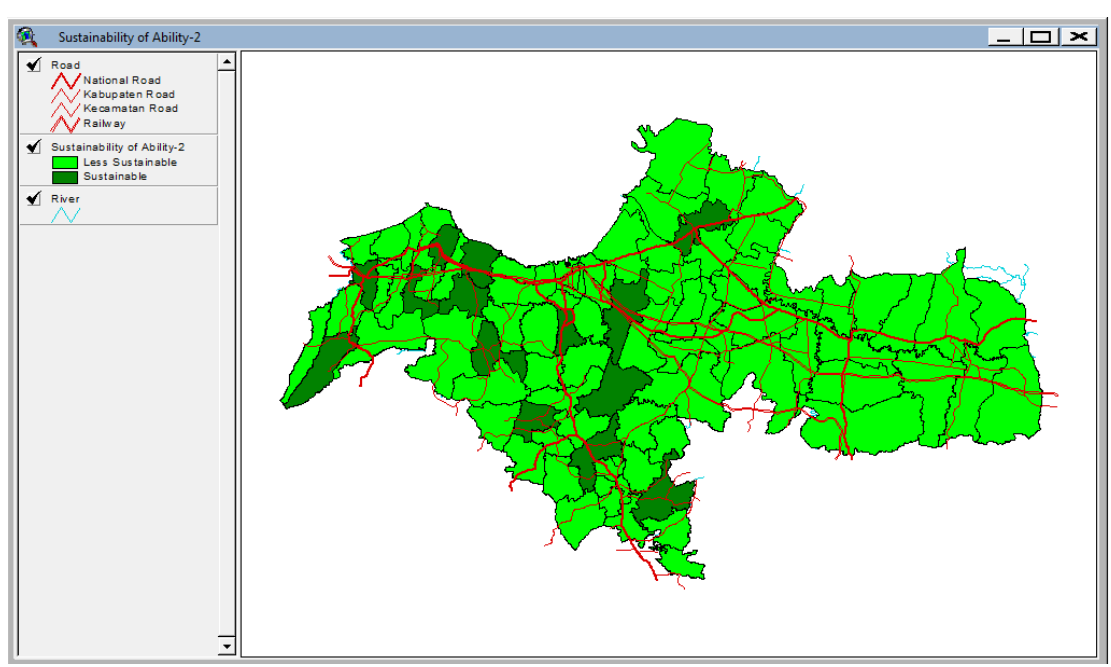

Fig. 9. Sustainability of Ability-2 of the SMR (Source: Authors) 


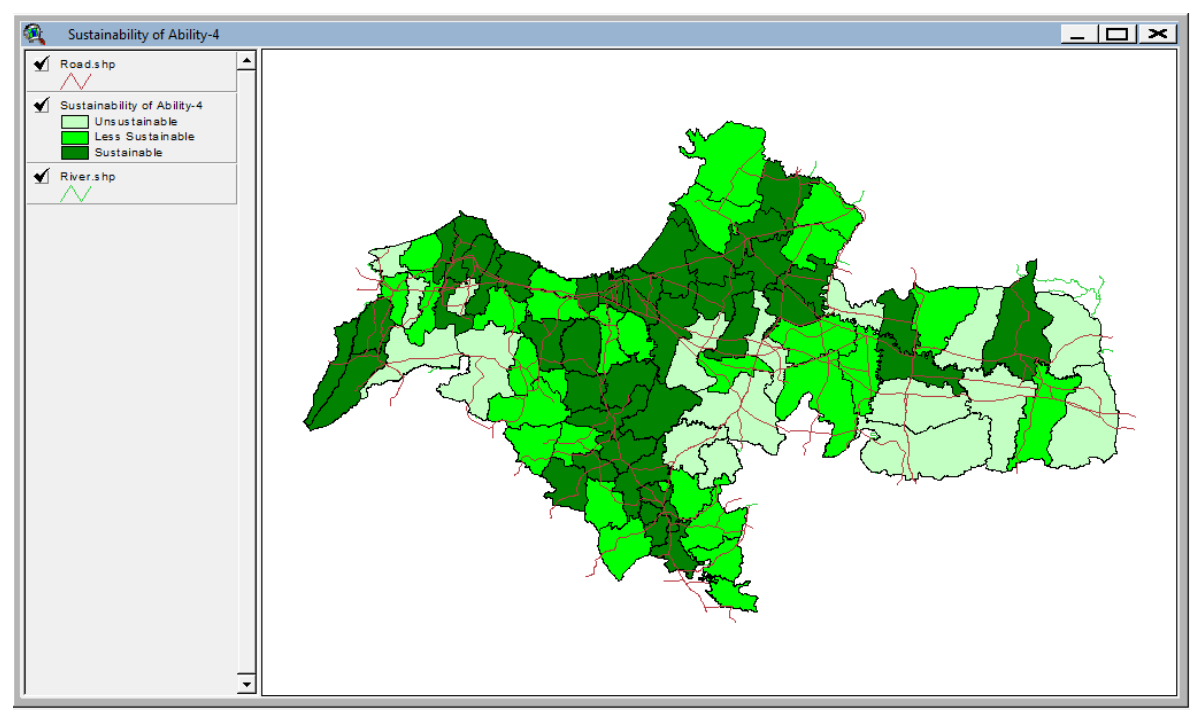

Fig. 10. Sustainability of Ability-4 of the SMR (Source: Authors)

These are important considerations for the near future. Another avenue is to mount an in-depth, continuing enquiry using several kecamatans as the case study. Assessment of the indicators proposed by Sugiri et al. (2011) shows that some suitable just for either urban or rural areas when applied at the kecamatan level. Several indicators such as percentage of existing land use for agriculture, scale of production of agriculture-related industries, investment in modern technologies in agriculture, number of extension personnel per areal unit of agriculture land, local knowledge applied in agriculture and regulations on the use of chemicals in agriculture are clearly designated for rural areas. Alternatively, the indicators of the ratio of trip generation between suburbs and the CBD, incentivesdisincentives for polluting industries and local regulation of industrial development are suited to urban areas. Besides, the indicators of the proportion of sprawl emerging within the built-up area and the growth rates of service coverage of local marketplaces are suitable when applied in the context of the metropolis as a whole. Therefore, contrasting the indicators for urban and rural areas should be a feature of further studies.

\section{Conclusion}

This research has developed a Geographic Information System (GIS)-based spatial model, supported by a complete and well-organized account of the Semarang Metropolitan Region stored in a GIS database system form. It is a simple Decision Support System (DSS), within which information can be queried down to district (kecamatan) level. The model is seen as a powerful tool that can help urban and regional managers identify some indications of unsustainability in a spatial context. By this early identification, they can formulate preventive policies to avoid any unsustainable trajectory within social and economic development planning.

The results show that the model is capable of documenting and assessing the level of sustainability of the SMR. However, the application reveals some shortcomings related to the determination of strategies and indicators of the original model. Of the 11 strategies proposed, only seven can be pursued for the whole metropolitan region. Among twenty-five indicators, only 11 are accessible at the kecamatan level and even then with some modifications. The lack of data at the kecamatan level, the high variance of data availability among cities and regencies and the fact that not all indicators are suitable for both rural and urban kecamatans form the main barrier to the model's application and development. To overcome the problem of lack of data, an in-depth study completed with intensive dissemination of the concept, due initiative and forwarding of initial results is proposed, so that awareness of the local decision makers of the Indonesian government can be improved. A study aimed at contrasting the proposed indicators for urban and rural areas is proposed to make the assessment more precise across the entirety of the chosen study area.

\section{Acknowledgement}

The paper is based on the first year results of a Diponegoro University-University of Queensland collaborative research funded by Ditlitabmas KLN research grant from the Ministry of Education and Culture of the Republic of Indonesia. 


\section{Author's Contributions}

Drs David Wadley and Yan Liu of The University of Queensland undertook a technical review and general editing of the completed paper.

\section{Ethics}

This article is original and contains unpublished material. The corresponding author confirms that all of the other authors have read and approved the manuscript and no ethical issues involved.

\section{References}

Arampatzis, G., C.T. Kiranoudis, P. Scaloubacas and D. Assimacopoulos, 2004. A GIS-based decision support system for planning urban transportation policies. Eur. J. Operat. Res., 152: pp: 465-475. DOI: $10.1016 / \mathrm{S} 0377-2217(03) 00037-7$

Barredo, J.I., M. Kasanko, N. McCormick and C. Lavalle, 2003. Modelling dynamic spatial processes: simulation of urban future scenarios through cellular automata. Landscape Urban Plann., 64: 145-160. DOI: $10.1016 / \mathrm{S} 0169-2046$

Black, W.R., 2009. A new approach to distributing urban trips. Int. J. Environ. Sustainable Dev., 8: 215. DOI:10.1504/IJESD.2009.024628

Buchori, I. and A. Sugiri, 2013. Developing sustainability assessment framework for metropolitan development: A GIS based analysis on Semarang. Semarang.

Buchori, I., 2005. Developing a spatial information system for regional planning in Indonesia: A case study of the rembang regency. $\mathrm{PhD}$ Thesis, HS Vechta, Vechta.

Bunch, M.J. and D.J. Dudycha, 2004. Linking conceptual and simulation models of the Cooum River: Collaborative development of a GIS-based DSS for environmental management. Comput. Environ. Urban Syst., 28: 247-264. DOI: 10.1016/S0198-9715(03)00021-8

Chang, Y.C., F.W. Hong and M.T. Lee, 2008. A system dynamic based DSS for sustainable coral reef management in Kenting coastal zone, Taiwan. Ecol. Modell., 211: 153-168.

DOI: $10.1016 /$ j.ecolmodel.2007.09.001

Chowdary, V., N. Rao and P.B. Sarma, 2003. GIS-based decision support system for groundwater assessment in large irrigation project areas. Agric. Water Manage., 62: 229-252. DOI: 10.1016/S0378-3774(03)00144-6

Countinho-Rodrigues, J., A. Simao and C.H. Antunes, 2011. A GIS-based multicriteria spatial decision support system for planning urban infrastructures. Decision Support Syst., 51: 720-726. DOI: $10.1016 /$ j.dss.2011.02.01
Czeranka, M., $1997 . \quad$ GIS-basierte

Entscheidungsunterstützung in der naturschutzorientierten Raumplanung (GIS-basic support system in the orientation of natural conservation of spatial planning). Vechtaer Druckerei und Verlag, Vechta.

Dassen, T., E. Kunseler and L. van Kessenich, 2013. The sustainable city: An analytical-deliberative approach to assess policy in the context of sustainable urban development. Sustainable Dev., 21: 193-205. DOI: 10.1002/sd.1550

De Kok, J.L., G. Englen, R. White and H.G. Wind, 2001. Modeling land use change in decisionsupport system $\mathrm{r}$ coastal-zone managemenfot. Environ. Model. Assess., 6: 83-86. DOI: 10.1023/A:1011587222253

De Meyer, A., R. Estrella, P. Jacxsens, J. Deckers and A. Van Rompaey et al., 2013. A conceptual framework and its software implementation to generate spatial decision support systems for land use planning. Land Use Policy, 35: 271-282. DOI: 10.1016/j.landusepol.2013.05.021

Despotakis, V.K., M. Giaoutzi and P. Nijkamp, 1993. Dynamic GIS Models for Regional Sustainable Development. In: Geographic Information Systems, Spatial Modeling and Policy Evaluations, Fischer, M.M. and P. Nijkamp (Eds.), Springer-Verlag. Berlin Heidelberg.

Firman, T., 2009. The continuity and change in megaurbanization in Indonesia: A survey of JakartaBandung Region (JBR) development. Habitat Int., 33: 327-339. DOI: 10.1016/j.habitatint.2008.08.005

Fischer, M.M. and P. Nijkamp, 1993. Geographic Information Systems, Spatial Modeling and Policy Evaluations. Springer-Verlag, Berlin Heidelberg.

Han, J., Y. Hayashi, X. Cao and H. Imura, 2009. Application of an integrated system dynamics and cellular automata model for urban growth assessment: A case study of Shanghai, China. Landscape Urban Plann., 91: 133-141. DOI: 10.1016/j.landurbplan.2008.12.002

Khadiyanto, P., 2005. Tata Ruang Berbasis Pada Kesesuaian Lahan (Spatial Management Based on Land Suitability). Universitas Diponegoro Press, Semarang.

Kyariga, A.T., 2001. GIS as a Decision Making Support Tool for Urban Planning and Management. In: The Symposium of the Computergestützte Raumplanung Computer Supports for Spatial Planning (CORP) 2001. Vienna-Austria.

Laurini, R., 2001. Information system for urban planning: A hypermedia co-operative approach. Taylor and Francis Inc., London. 
Marceau, D.J., L. Guindon, M. Bruel and C. Marois, 2001. Building temporal topology in a GIS database to study the land use change in a rural urban environment. Profess. Geographer, 53: 546-558. DOI: 10.1111/0033-0124.00304

McClean, A.C. and R. Fuller, 1995. The Integration of Three Land Classifications Within a Decision Support System for Land Use Planning. In: Innovations in GIS 2: Papers from the Second National Conference on GIS Research UK, Fisher, P. (Ed.), Taylor and Francis Ltd., London.

Mubyarto, 1998. Ketimpangan Antardaerah Penyebab Krisis Ekonomi (Regional Inequality as the Cause of Economic Crisis). Suara Merdeka daily.

Mukaryanti, 1997. The assessment of coastal zone development issues: A study of Banten bay coastal zone-West Java. The University of Queensland.

Nyerges, T., 1999. Progress in Spatial Decision Making Using Geographic Information System. In: Geographic Information Research: Trans-Atlantic Perspectives, Craglia, M. and H. Onsrud, (Eds.), Taylor and Francis Ltd., London.

Pearce, D.W. and J.J. Warford, 1993. World Without End: Economics, Environment and Sustainable Development. Oxford University Press, Oxford.

Pearce, D.W., A. Markandya and E.B. Barbier, 1989. Blueprint for a Green Economy. Earthscan, London.

Schotten, K., R. Goetgeluc, M. Hilferink, P. Rietveld and H. Scholten, 2001. Residential construction, land use and the environment. Simulations for the netherlands using a GIS-based land use model. Environ. Model. Assess., 6: 133-143. DOI: $10.1023 / \mathrm{A}: 1011531120436$

Soetomo, S., 2009. Urbanisasi dan Morfologi, Proses Perkembangan Peradaban dan Wadah Ruang Fisiknya: Menuju Ruang Kehidupan yang Manusiawi (Urbanisation and Morphology, Development Process and Its Spatial Dimensions: Towards Civilized Life Space). Graha Ilmu, Yogyakarta.

Sugiri, A. and I. Adiputra, 2011. Natural resources for local people's welfare? People participation in oil governance of cepu block, Indonesia. Int. J. Arts Sci., 4: 169-87.

Sugiri, A., 2008. Aplikasi Keadilan dalam Kebijakan Publik: Solusi Menyeluruh terhadap Masalah Kemiskinan di Indonesia (Equity Application in Public Policy: A Comprehensive Solution to Poverty in Indonesia). Proceedings of the National Seminar of Postgraduate Research VIII, (SPR' 08), Institute of Technology Sepuluh November (ITS), Surabaya.
Sugiri, A., 2009. Redressing Equity Issues in Natural Resource-rich Regions: A Theoretical Framework for Sustaining Development in East Kalimantan, Indonesia. In: Environmental Ethics: Sustainability and Education, Weber, E. (Ed.), Inter-Disciplinary Press, Oxford, pp: 107-35.

Sugiri, A., I. Buchori and S. Ma'rif, 2014. Towards participatory spatial policy: Facilitating rural nonfarm activities in Susukan suburb of Semarang metropolitan region. Int. J. Civic Political Community Stud.

Sugiri, A., I. Buchori and S. Soetomo, 2011 Sustainable metropolitan development: Towards an operational model for Semarang Metropolitan Region. Int. J. Environ. Cultural Econ. Soc. Sustainability, 7: 301-323.

WCED, 1987. Our Common Future. Oxford University Press, Oxford.

Wegener, M., 1999. Spatial Models and GIS. In: Geographic Information Research: Trans-Atlantic Perspectives, Craglia, M. and H. Onsrud (Eds.), Taylor and Francis Ltd., London.

Xiaodan, W., Z. Xianghao and G. Pan, 2010. A GISbased decision support system for regional ecosecurity assessment and its application on the Tibetan Plateau. J. Environ. Manage., 91: 1981-90. DOI: 10.1016/j.jenvman.2010.05.006

Yeh, A.G., 1999. Urban Planning and GIS. In Geographical Information System Vol. 2: Management Issues and Applications, Longley, P.A., M.F. Goodchild, D.J. Manguire and D.W Rhind (Eds.), John Wiley and Sons Inc., New York.

Yeo, I.A., S.H. Yoon and J.J. Yee, 2013. Development of an Environment and energy Geographical Information System (E-GIS) construction model to support environmentally friendly urban planning. Applied Energy, 104: 723-739.

Zeng, H., A. Talkkari, H. Peltola and S. Kellomäki, 2007. A GIS-based decision support system for risk assessment of wind damage in forest management. Environ. Modell. Software, 22: 1240-1249. DOI: 10.1016/j.envsoft.2006.07.002 